\title{
P-32 THE NILE DEEP-SEA FAN: INTERFERENCE BETWEEN SEDIMENTATION AND TECTONICS
}

G. BELLAICHE', L. LONCKE', J. MASCLE', V. GAULLIER ${ }^{2}$, L. DROZ ${ }^{3}$ and the shipboard scientific party 'Géosciences-Azur/UMR 6526, PO Box 48, 06235 Villefranche-sur-mer ${ }^{2}$ CEFREM

${ }^{3}$ UMR6538/ institut Universitée Européenne de la Mer

\section{Summary}

The Nile deep-sea fan has recently been surveyed using swath multibeam bathymetry, backscatter imagery, and seismic profiling. Three main morpho-structural and sedimentary provinces are recognized. A western domain is characterized mainly by growth faults and a dense network of sinuous distributary channels. A central province shows segments of sinuous channels, major growth faults, and salt ridges isolating ponded basins. An eastern province is an area of intense faulting interpreted as northward extension of the Suez Rift. In most of the areas salt diapirs, emplaced along faults and widespread layers of debris-flows are observed.

The Nile deep-sea fan is the most conspicious terrigenous accumulation within the Mediterranean sea. Its sedimentary architecture has been partly studied some 20 years ago $(1,2$, 3 ), but the details of its surficial and subsurface features are not well known. The Prismed II survey, carried out onboard the N/O l'Atalante on February 98, has allowed to explore this fan using multibeam bathymetry, acoustic imagery, and seismic profiling. The bathymetry, based on the results of a Simrad EM 12 Dual multibeam sounding system, allowed a complete coverage of the study area. Detailed acoustic imagery of the seafloor has also been obtained using the same system. Sub-bottom sedimentary structures were imaged down to depth of $0-50 \mathrm{~m}$ using a 3.5 $\mathrm{kHz}$ profiler and deeper structures, up to $3 \mathrm{std}$ were evidenced using a six-channel hydrophone streamer and a single Gi gun. This survey established that the Nile deep-sea fan can be divided into three main morphologic, sedimentary and tectonics provinces (4):

A western Province is characterized by a dense network of meandering distributary channels over more than $200 \mathrm{~km}$ and trending northwestwardly. These channels are flanked by sedimentary levees that might rise one hundred meters above the thalwegs within the upper fan and on the order of twenty meters distally. The backscatter records show sharp contrasts between the channels (dark tones) and their levees (clear tones). Bathymetry as well as backscatters suggest that the western channels are more recent than the eastern ones, suggesting thus westerly progressive avulsion processes. In details, the channel system displays characteristic bed-forms typically observed in deep-sea fans such as crevasse splays, abandoned channels, compressional ridges linked with levee collapses etc. Downslope, darker tones of the seafloor seen on the acoustic imagery, might indicate widespread sandy deposits due to channel discharges. In the northernernmost part of the study area, near the Mediterranean Ridge front, the turbiditic deposits are progressively folded.

On the upper continental slope, the seismic basement is believed to correlate with the messinian unconformity, which appears as an erosive surface locally filled with strongly reflective or transparent sediments. Offwards, this surface is laterally passing to typical messinian evaporitic 
layers, giving rise locally to salt diapirs. A series of growth faults, well expressed on the seismic profiles, are closely linked to the underlying messinian salt. In some case the vertical throw of these faults may reach $200 \mathrm{~m}$, and the offset sediment thickness exceeds $2000 \mathrm{~m}$. Layers of acoustically chaotic deposits, locally very thick (up to $0.7 \mathrm{~s}$ in places), interpreted as debrisflows, appear interbedded within the Quaternary turbiditic cover of the fan. We assume that such debris-flows originate from the upper slope, and more precisely from the Rosetta canyon head.

A central Province is chiefly characterized at mid-slope by a $200 \mathrm{~km}$ long belt of almost continuous slump scars. These spoon shaped scars, E-W to NE/SW trending, may reach 100-200 $\mathrm{m}$ in elevation. Although the seismic profiles, due to their orientation, do not allow to recognize their structure, we believe very likely that they are growth faults related to thin-skinned extension above the Messinian salt layer, acting as plane of decollement. In this province, PlioQuarternary sediment thickness is about $2 \mathrm{~s}$. In large areas of west of this province, seismic profiles show that the interbedded debris-flows are close to the sea-floor. They may even be observed on the backscatter images where they are characterized by dark irregularies amid light surfaces.

This area is also characterized by two well expressed channels showing a clear westward migration. In the same area the backscatter records show very numerous black dots, interpreted as pock marks. The $3,5 \mathrm{kHz}$ profiles recorded in this location, show hyperbolic reflectors that may correspond to gas seeps.

Offwards the growth faults domain, the central province is affected by a series of roughly N-S oriented salt ridges forming structural highs separating slightly depressed sedimented basins. These basins contain very regular and horizontally bedded reflectors characterized by very clear tones on the backscatter records. We tentatively interpret them as homogenites deposits. Anywhere else, despite slumping and rough morphology, sinuous channels can be readily traced.

An eastern province: both the bathymetry and imagery show a sharp contrast between this domain and the previous one. The transition to the Eastern province is sharply marked by a NNW-SSE trending major fault that can be recognized over more than $100 \mathrm{~km}$. This fault constitutes the westernmost boundary of a faulted zone which also seem to shape the southwestern edge of Eratosthenes Seamount. Orthogonally to these deeply rooted faults, sigmoidal grabens are recognized. Seismic reflection data indicate that all these normal structures are intruded by late Miocene salt diapirs (5). All observed features support that the major faults that bound the grabens, have an horizontal component and may be interpreted as transtensive faults with a right lateral displacement. We believe that the deformation reflects salt reactive response to regional transtensional deep-seated geodynamic, combined with active gravitational gliding $(6,8)$. Fault activity seems to be indicated by surficial sediments showing transparent echo-characters on the 3-5 profiles. In this highly tectonized eastern province, the nilotic network system appears to be very segmented, and locally, faults channeled the turbiditic sedimentation.

Near Eratosthenes Seamount, the Nile delta front is marked by a steep and narrow bathymetric scarp (more than $500 \mathrm{~m}$ high) similar to the Sigsbee scarp of the northern Gulf of Mexico (7). There, the salt layer seems to have been expelled and inflated by the combined loading and seaward translation of the prograding sediments of the Nile deep-sea fan.

Finally, east of Eratosthenes Seamount, an isolated network of deep-sea channels, oriented NNW-SSE towards the Cyprus continental margin, can be observed. We believe that this network is not directly associated with the nilotic distributary system, but might be related to sedimentary sources originating from the Central Levantine slope. 
In conclusion we may state the following: the sedimentary distributary systems of the Nile deepsea fan have been illustrated in details. Feeding channels are very extensive especially within the western province where they show complex meandering patterns. Our data document a progressive channel migration towards the west suggesting thus a regular subsidence of the western fan province potentially associated with a global uplift of the eastern one. Evidences for active or recent tectonic activity are abundant: the upper continental slope is shaped by growth faults leading to downslope huge debris-flows. Compressive tectonic is observed distally, near the front of the Mediterranean ridge. Across the eastern province, NNW-SSE trending fault systems probably related to an offshore extension of the Gulf of Suez Rift system, delimit a well individualized Levantine-Sinai microplate (8). Salt diapirs are clearly emplaced along many of these faults. The underlying messinian salt layers appear thus to play a key role on the present sedimentary distribution and the deformation of the entire Nile deep-see fan.

\section{References}

(1) KENYON, N.H., STRIDE, A.H. and BELDERSON, R.H., 1975, Plan views of active faults and other features on the lower Nile cone, G.S.A. Bull., 86, 1733-1739.

(2) ROSS D.A. and UCHUPI E., 1977. The structure and sedimentary history of the southeastern Mediterranean Sea. Am. Ass. Petrol. Geol. Bull., 61: 872-902.

(3) STANLEY D.J. and MALDONADO A.,1977, Nile cone: Late quaternary stratigraphy and sediment dispersal, Nature, vol. 296: 129-135.

(4) BELLAICHE G., ZITTER T., DROZ L., GAULLIER V., MART Y., MASCLE J. et l'équipe scientifique embarquée, 1999, Le cône sous-marin profond du Nil: principaux résultats de la campagne "Prismed II", C.R. Acad. Sc. Paris, t. 329, série II a, p.727-733.

(5) KEMPLER D., MART Y., HERUT B. and MCCOY F., 1996. Diapiric structures in the SE Mediterranean. Mar. Geol., 134: 237-248.

(6) GAULIER V., MART Y., BELLAICHE G., MASCLE J., VENDEVILLE B., ZITTER T. and the shipboard scientific party, Salt Tectonics in and around the Nile Deep-Sea Fan (Geological Soc., spec. paper, in press).

(7) JACKSON M.P.A. and GALLOWAY W.E., 1984, Structural and depositional styles of Gulf Coast tertiary continental margins, $A A P G$., Bureau of Economic Geology, Texas University, $226 \mathrm{p}$.

(8) MASCLE J., BENKHELIL J., BELLAICHE G., ZITTER T., WOODSIDE J., LONCKE L. and the Prismed II Scientific Party, Marine geological evidence for a Levantine-Sinai plate (submitted to Geology).

Please note that this abstract has been retyped and the figures are scanned, as it was not received in a digital format. EAGE cannot be held responsible for any typing errors that may occur nor for any results that might arise from scanning the figures in this text. 


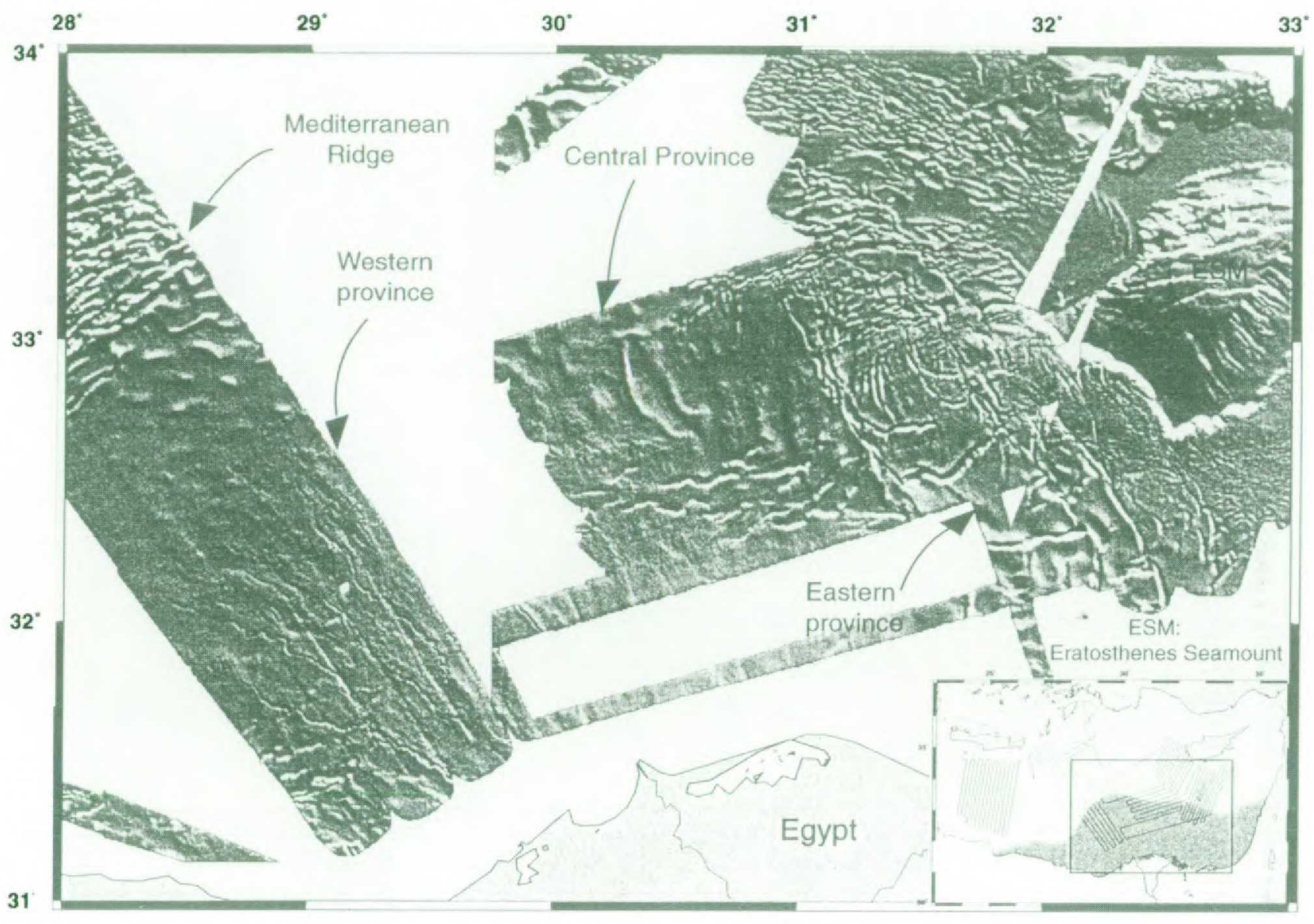

